\title{
Corporate Governance and Performance in Publicly Listed, Family-Controlled Firms: Evidence from Taiwan
}

IGOR FILATOTCHEV

King 's College London, UK, 150 Stamford St, London SE1 9NN

igor.filatotchev@kcl.ac.uk

YUNG-CHIH LIEN

fred_lien@hotmail.com

Chung-Hua Institute for Economic Research, Taiwan

jenifer.piesse@kcl.ac.uk

JENIFER PIESSE

enbosch, RSA

\begin{abstract}
Using a multi-industry dataset of 228 firms listed on the Taiwan Stock Exchange (TSE) this paper analyses the effects of ownership structure and board characteristics on performance in large, publicly traded firms that are controlled by founding families. After taking account of possible endogeneity problems, we do not find that family control is associated with performance measured in terms of accounting ratios, sales per issued capital, earnings per share and market-to-book value. However, share ownership by institutional investors, and foreign financial institutions in particular, is associated with better performance. Our results indicate that board independence from founding family and board members' financial interests have a positive impact on performance.
\end{abstract}

Keywords: family ownership, governance, performance

There is a growing body of research in the economics and management literatures that links general governance factors, such as the pattern and amount of stock ownership and board characteristics, with strategic decisions (e.g., Bruton, Ahlstrom, \& Wan, 2003; Filatotchev, Buck, \& Zhukov, 2000; Hambrick \& Jackson, 2000; Hoskisson, Johnson, \& Moesel, 1994), and, eventually, corporate performance (e.g., Cho, 1998; Dalton, Daily, Certo, \& Roengpitya, 2003; Daily \& Dalton, 1992; Demsetz \& Lehn, 1985; Hansmann, 1996). Despite this wealth of research, mainly grounded in an agency framework, little is known about ownership-performance inter-relationships outside Western, particularly the US, environments of widely-held public corporations (Bruton et al., 2003). More specifically, there is a dearth of research on their determinants in family-controlled but publicly listed firms (Gomez-Mejia, Larraza-Kintana, \& Makri, 2003), which represent a significant part of the corporate sector in many developed and developing countries (Chang, 2003; La Porta, Lopez-De-Silanes, \& Shleifer, 1999). Daily, Dalton, and Rajagopalan (2003: 155) indicate "agency effects may function differently in this context and that prior findings from non-family samples may not readily generalize into this setting". 
Family-controlled firms play a particularly important role in Asian countries (Chang, 2003; Joh, 2003), but, with the exception of Japan, most studies of corporate governance related to Asian countries prior to 1998 rely on case study methods of specific industrial sectors (for example, Taniura, 1989, 1993; Numazaki, 1993). While many have produced interesting results the overall picture of corporate governance in the region remains ambiguous. More recently, the financial crisis in South East Asia has resulted in a plethora of research that has concentrated on the importance of models of corporate governance in countries that are largely organised through a system of family control and ownership of firms (e.g., Anderson, Mansi, \& Reeb, 2003; Bruton et al., 2003; Carney \& Gedajlovic, 2003). These studies tend to focus on the impact of various forms of family ownership on firm performance, attributing corporate vulnerability to the degree of family involvement.

However, a number of Asian countries did not experience a dramatic fall in economic performance during the crisis period, while still maintaining a close family ownership structure (Rajan \& Zingales, 1998). This is not totally surprising, since the economic environment within countries of the region is substantially different, despite common elements such as cultural background, the nature and extent of institutions and the level of economic development. A single model of corporate governance for all Asia is unlikely although Mitton (2002) found that governance mechanisms, especially monitoring activity, are critical to corporate performance. However, to what extent this varies across individual countries is still unclear. Thus, this paper focuses on a single country, Taiwan.

Taiwan is a model for newly emerging economies. Since WWII, high levels of economic development have been achieved, due largely to a national policy of promoting manufacturing in the information technology sector. But, at the same time, excessive capital from trading surpluses and property appreciation in an immature and poorly regulated local market has encouraged opportunistic behavior by both investors and corporate managers. This sometimes reckless expansion can result in failure and an over-dependence on financial leverage leading to exploitation of minority investors. Therefore it is important that a robust system of governance is in place, particularly in the areas of corporate management, equity trading and foreign investment if the Taiwanese successful story is to continue. This paper examines links between family control and performance in firms operating in a single legal and institutional environment, and permits us to hold constant a number of important contextual factors. This avoids endogeneity problems between ownership structure and country-specific institutional characteristics (Carney \& Gedajlovic, 2002; Joh, 2003).

The Taiwanese corporate sector represents an important research laboratory that provides an opportunity to develop further previous research and to make a number of contributions. First, it allows us to analyze corporate governance effects on performance in situations where the managers are frequently family members, where families are also represented on a firm's board, and where they are often the major providers of capital, if not directly, then through relational holdings in other firms (Bruton et al., 2003; Carney \& Gedajlovoc, 2003). At the same time, family-controlled firms that are listed on the stock exchange also have minority shareholders to whom managers are accountable, and the governance effects of the interaction of family control with external share ownership on performance is therefore an important research issue. Second, the process of maturity and globalization of Taiwanese capital markets is accompanied by an increase in importance of institutional investors, both 
domestic and foreign. Building on an integrated research framework developed by Agrawal and Knoeber (1996) and Aderson and Reeb (2003), this paper examines the extent to which concentrated shareholdings by institutions can influence firm performance, similarly with non-family representation on corporate boards. Finally, an improvement in reporting and disclosure standards in Taiwan presents an opportunity for a relatively rigorous empirical study using firm-level data. This paper provides an analysis of governance-performance relationships using a multi-industry dataset of 228 firms listed on the Taiwan Stock Exchange (TSE), while taking account of possible endogeneity problems.

The paper begins with a discussion of the institutional structures in Taiwan, with particular emphasis on the custom and practice of family ownership and the regulatory system of board membership and control. Section two outlines the literature on which the examination of the role of corporate governance in firm performance is based and develops a number of research hypotheses. The next section briefly describes the data used in the empirical analysis, followed by the results and a discussion of the findings. The final section concludes.

\section{The institutional framework of corporate governance in Taiwan}

The legal framework of corporate governance in Taiwan is based both on Company Law, which defines the contractual relationship between management and the providers of capital, and Securities and Exchange Law that is directed towards more widely held publicly-traded companies to ensure adequate disclosure and transparency necessary for efficient financial market operations. The Securities and Futures Commission (SFC) is the market regulator for the Taiwan Stock Exchange (TSE), with responsibility for issuing new securities, ensuring timely disclosure of company financial information and regulating market intermediaries, trading and settlement. Taiwanese companies operate with a board of directors and a number of supervisors, similar to that in Japan, although there are a number of differences. According to Company Law (provision 192), the board should be composed of a minimum of three directors who have a responsibility to maintain the value of the firm and ensure good practice in terms of audit, transparency and accountability. Directors are formally elected at the general meeting of shareholders, and they usually nominate a CEO and/or Board Chairman. To be confirmed in these top positions requires support of at least half the executive directors.

The Company Law (sections 216-227) also specifies that Taiwanese companies should have supervisors, much as the Japanese kansayaku. However, the supervisors in Taiwan are explicitly defined not as a board but as individuals that take responsibility for independent monitoring. They do not meet and act as a board, and there is no minimum number specified. Before the general meeting of shareholders, significant shareholders normally negotiate amongst themselves to select the list of directors and supervisors, and the outcome of this bargaining process very much depends on family networks and contacts. On rare occasions when consensus cannot be achieved, significant shareholders prepare an election campaign and try to secure proxy votes of minority investors.

Board organisation and functions in Taiwan are clearly a departure from not only the US and UK, but also from Japan and neighbouring Hong Kong and Singapore. Alternative single boards models rely on non-executive directors to undertake a monitoring role, with 
the discipline of the market providing a robust controlling mechanism (e.g., Arthur, 2001; Baysinger \& Butler, 1985; Golden \& Zajac, 2001). However, the system in Taiwan does not resemble formal two-tier systems either. For example, France and Germany ensure effective monitoring by common consensus of the supervisory board, which has wide powers of scrutiny with respect to management and the right to select and remove members of the board of directors (Zeckhauser \& Pound, 1990). This can be the responsibility of a single supervisor in Taiwan. Another aspect of board composition that separates governance models in Taiwan and Japan from other countries is the lack of any formal representation from labor. Finally, the family owners have a great deal of discretion in terms of board appointments and leadership structure.

Mandatory equity ownership by directors and supervisors in listed companies in Taiwan is a further factor that differentiates Taiwanese corporate governance from not only conventional US/UK model but also other SEA countries. In order to align directors' interests with maintaining the objective of contributing to corporate value, the market regulator sets a minimum shareholding associated with all members of the Board of Directors and the supervisors, ensuring that no outsider is formally required to be part of the governance system (see Table 1). This is now beginning to change, but extremely slowly.

Companies are required to report trading activity by board members, supervisors and any other shareholders with more than $10 \%$ of equity in the firm to the SFC. In particular, the SFC is interested in any change in the amount of collateralized equity in the firm. This appears to be peculiar to the Taiwanese corporate sector and does not exist in other systems of shareholder-based corporate governance.

Taiwan has achieved an advanced level of economic development, but there is still evidence of an emerging entrepreneurial capitalism and in many cases, firms retain family ownership and control. Even in publicly traded companies with minimal shareholding by founding families, there is the perception of family ownership and thus the approach to corporate governance is confused. As a consequence, there is a close relationship between the board of directors and the supervisors in the vast majority of Taiwanese firms. Wealth Magazine (2002) found that five leading manufacturing companies, including the largest listed on the TSE, had a husband and wife in the role of board chairman and supervisor, respectively, weakening the monitoring system altogether. This has highlighted the need for a further examination of the structure of corporate governance overall, where family ownership and control can be so distortionary.

Table 1. Statutory shareholding for officers in listed companies.

\begin{tabular}{lcc}
\hline & \multicolumn{2}{c}{ Minimum required shareholding } \\
\cline { 2 - 3 } Firm capitalisation (New Taiwanese \$) & Board of directors (\%) & Supervisors (\%) \\
\hline$<300$ mil NT\$ & 15 & 1.5 \\
300 mil NT\$-1000 mil NT\$ & 10 & 1.0 \\
1000 mil NT\$-2000 mil NT\$ & 7.5 & 0.75 \\
$>2000$ mil NT\$ & 5.0 & 0.5 \\
\hline
\end{tabular}




\section{Theoretical background and research hypotheses}

\section{The effect of family owners on corporate performance}

Few empirical studies consider organisational performance of publicly owned, family controlled firms directly, although Claessens, Djankov, and Lang (2000) confirms that a large proportion of listed companies are still under family control in a number of countries in East Asia, including Taiwan. Further, more than two-thirds of listed firms in East Asian countries are controlled by a single shareholder with $60 \%$ of managers in these companies members of the family of the controlling shareholder. Clearly, this is the common model of corporate governance in the region (Bruton et al., 2003). At the same time, corporate control in East Asia is largely dependent on a pyramid ownership structure with equity cross-holding amongst associated firms making the separation of ownership and control very unlikely. Furthermore, not only is this model of governance prevalent in small and medium sized enterprises, it is also replicated in large scale public trading companies in Taiwan, as well as in Korea and Singapore.

In an attempt to explain this phenomenon, La Porta et al. (1999) claim the popularity of family controlled companies results from inadequate protection of investor rights by national institutions. In a survey of large corporations in 27 high per capita income countries, only those with high levels of investor rights protection exerted adequate monitoring of the few firms that were controlled by single shareholders or a dominant family. Claessens et al. (2000) in a study of East Asian countries indicate that controlling families generally use pyramidal ownership structures to ensure a disproportionately high level of controlling rights as well as cash flow rights.

A number of researchers express concerns about the problems associated with family control, and the increased likelihood of the abuse of managerial power. Research from North America in particular, (e.g. Morck, Shleifer, \& Vishny, 1988, Smith \& Amoako-Adu, 1999) provides evidence of the negative effect of a controlling family on corporate performance. In addition, strategy research identifies family firms to be altruistic in the relationship between parents and their children (Schulze, Lubatkin, Dino, \& Buchholtz, 2001), which may have an impact on the effective succession process when the founder retires. Moreover, family interest may dominate over the interest of non-family shareholders, since the concentration of personal and family wealth in owner-managed firms normally creates a preference for income and for wealth preservation over other dimensions of firm performance such as maximisation of dividend payments to outside shareholders (Carney \& Gedajlovic, 2003). Finally, family control tends to shield a firm from the disciplinary pressure of the market for corporate control since concentrated share ownership reduces the probability of a hostile take-over (Gomez-Mejia, 2003)

However, whether families or professional managers run companies better for society in general is still open to debate. During the current prolonged recession, corporate scandals and the collapse of stock markets have resulted in a return to the kind of values prevalent in family-owned companies. Family businesses that survived their own internal succession dramas have tended to take a longer-term view rather than live and die by stock market evaluation of their performance (Bruton et al., 2003). Because of the extension of altruism 
from the family system to the firm, owners in the current generation have the tendency and obligation to reserve wealth for the next generation. As a result, family firms often possess longer horizons compared to non-family firms (James, 1999). Family firms, therefore, represent a special class of large shareholders that may have a unique incentive structure, a strong voice in the firm, and powerful motivation of managers (Demsetz \& Lehn, 1985). Anderson et al. (2003) suggest that these characteristics can alleviate agency conflicts between the firms' debt and equity claimants and reduce the agency costs of debt. Because the family's wealth is so closely linked to firm welfare, families may have strong incentives to monitor managers and minimize the free-riding problem inherent with diffused shareholders. If monitoring requires knowledge and information about firm technology and processes, families potentially provide superior oversight because of their lengthy involvement with the firm (Anderson \& Reeb, 2003: 1305).

Studies on emerging economies have developed this research further and uncovered other important institutional factors that may contribute to governance outcomes of family control, such as the development of market institutions, the level of government involvement, industry structures, and enforcement of business laws (Chang \& Hong, 2000; Khanna \& Palepu, 1997, 2000; La Porta, Lopez-de-Silanes, Shleifer, \& Vishny, 1998; North, 1994). For example, Filatotchev et al. (2000) indicate that managerial opportunism in transition economies is not controlled effectively by new owners of the privatized firm, arguing that their monitoring is constrained by difficulties in gaining board seats in employee dominated firms, by weak legal enforcement, weak external capital market forces and volatile product markets. This leads to the suggestions that family ownership can create a counter-balance to a fluid state of the institutional environment in emerging market economies and the retention of control by founding families may be positively associated with performance outcomes (Newman, 2000).

In addition, strategy analysis of corporate governance (Filatotchev \& Bishop, 2002) views family control as less of a problem as it could be a potential provider of more useful resources and a possible enhancement of firm value. In fact, La Porta and Lopez-De-Silanes (1997) find that poorer investor protection by national legal systems is associated with smaller and more illiquid capital markets supporting the view that private finance could be vital and a scarce resource for corporate growth in these countries. In economies with immature capital markets and few professional managers, many family firms are established by obtaining capital and human investments from families and personal networks (McConaughy, Matthews, $\&$ Fialko, 2001). Furthermore, through business networks, uncertainties and complexity are reduced because information is shared and circulated among the participants in the network, resulting in better monitoring of activities both within and between firms. This is especially effective in East Asia as financing is relationship-based, and the presence of owners in family-controlled firms should be associated with better growth and higher firm value.

These arguments suggest that family ownership can lead to better monitoring of managerial discretion and reduce principal-agent costs associated with diffused share ownership structures. It can also facilitate access to resources. As a result, family presence in the firm may provide a competitive advantage and improve short- and long-term performance (Anderson \& Reeb, 2003). A number of more recent empirical studies provide evidence that 
controlling family ownership is associated with better performance in South Korea (Chang, 2003; Joh, 2003) and Hong Kong (Carney \& Gedajlovic, 2002). Building on the agency and institutional analyses of performance effects of family ownership and control, we suggest:

H.1. In Taiwan, family ownership and control are positively associated with performance.

\section{Institutional investors and corporate performance}

The above arguments suggest that, other things being equal, family control over the firm may be associated with superior oversight and strong incentives to monitor managers that should mitigate principal-agent costs. However, when organizations grow, the limited financial and managerial resources of a founding family impose constraints on development. Although family control may be a way to resolve agency problems, the lack of owner support for new investment results in the need to access capital market funding and increasing importance of attracting external, non-family shareholders. Families can seek to maximize firm performance but yet still create severe conflicts over the distribution of wealth among different groups of shareholders (Anderson \& Reeb, 2004). As a result, the primary agency problem in this environment is not the failure of professional managers to satisfy the objectives of diffused shareholders, but rather the expropriation of minority shareholders by the family interests (Bruton et al., 2003; La Porta, Lopez-De-Silanes, Shleifer, \& Vishny 2000a), what Young, Peng, Ahlstrom, and Bruton (2002) call a "principal-principal" or "horizontal" agency relationship. The potential for moral hazard conflict between the family and outside shareholders creates a new set of agency costs, including mutual monitoring and opportunity costs, that may have an adverse effect on the firm. Therefore, divestments through sales of large blocks of shares to institutional investors may be a viable alternative to ownership dispersion from the minority shareholders point of view (Hansmann, 1996; Shleifer \& Vishny, 1997).

A number of studies in the US suggest that large block outside ownership may have a positive impact on firm performance. Companies may have large groups of undiversified shareholders that play a critical leadership and monitoring role. They have both the incentives and the means to restrain the self-serving behaviour of managers (Maug, 1998; Zeckhauser \& Pound, 1990). For example, using structural equation modelling, Hoskisson et al. (1994) showed that block shareholders may not allow a poor strategy such as diversification to evolve into poor performance, therefore decreasing the magnitude of restructuring. Wruck (1989) provides empirical evidence that when managers have an opportunity to conduct a self-serving deal that damages shareholders, the decision to sell a block of securities to non-management investors increases shareholder wealth. Finally, the study by McConnel and Servaes (1990) suggests a positive relationship between institutional share ownership and Tobin's Q. However, this research is focused on the governance roles of large block outside investors in reducing costs associated with "vertical" principal-agent relationship problem, and their impact on "horizontal", principal-principal agency relationship is not well understood.

Institutional aspects of corporate governance in Taiwan bring new and interesting dimensions to this debate. Investment opportunities in the Taiwanese capital markets have 
increasingly attracted both domestic and overseas investors. However, the relatively illiquid capital market provides an effective constraint on institutional investors' ability to create and manage a risk-free portfolio. At the same time, institutional investors acquire shares in listed firms that also have a substantial family block-holding (Bruton et al., 2003). Anderson and Reeb $(2003,2004)$ suggest that when families are in exceptional control positions, the presence of large external investors can mitigate the potential for moral hazard conflict between the family and outside shareholders. In addition, when control is dissipated among several large investors, a decision to expropriate minority shareholders requires the consent of a coalition of investors, and this coalition might hold enough cash flow rights to choose to limit expropriation of the remaining shareholders and pay the profits as efficient dividends (La Porta et al., 2000a). In this particular case, an entrenchment effect associated with individual shareholdings of the coalition's members may be dominated by the JensenMeckling incentives generated by the combined coalition's share ownership. For example, Bennedsen and Wolfenzon (2000) suggest a theoretical model explaining an alignment effect of a coalition of large shareholders, that is a positive relation between the cash flow stake of the controlling coalition and total firm value. Therefore, in Taiwan, presence of institutional investors may be complementary to family control in terms of its positive effects on firm performance (Gomes-Mejia et al., 2003) and it can mitigate agency costs of what Young et al. (2002) call a "principal-principal" agency relationship. Building on this research, we suggest that:

H.2. In Taiwan, the share ownership of outside institutional investors is positively associated with performance.

Most research on performance effects of institutional share ownership, however, has not differentiated among types of investors (Hoskisson, Hitt, Johnson, \& Grossman, 2002). Only recently have studies acknowledged that the identity of such owners has important organizational implications because different owners may have different objectives and decisionmaking horizons (Tihanyi, Johnson, Hoskisson, \& Hitt, 2003: 197). For example, banks and investment trusts may behave differently in terms of their strategic preferences (see Chang, 2003; McConnell \& Servaes, 1990, for a discussion). Some authors (e.g., Brickley, Lease, \& Smith, 1988; Kochar \& David, 1996) differentiate between "pressure-resistant" and "pressure-sensitive" institutional investors. Pressure-resistant institutions, such as investment funds, are unlikely to have strong business links with their investors, and they may have stronger influence on strategy choices and their performance outcomes (Hoskisson et al., 2002). Johnson and Greening (1999) also indicate that investment fund managers' objective is a high relative performance of their portfolio firms because of their own reward system. On the other hand, "pressure-sensitive" investors such as banks are likely to have business relationships with the firms in which they invest (Kroszner \& Strahan, 2001). Because they often have an obligation to support the management's agenda, their governance role tends to be more passive compared to "activist" investors (Tihaniy et al., 2003). Previous research widely acknowledged overlapping long-term business and investment relationships between banks and industrial companies in East Asia and their potentially detrimental effects on performance (Bruton et al., 2003; Chang \& Hong, 2000; Mitton, 2002). 
In addition, a number of studies in the international business field recognise that foreign institutional investors are more likely to produce positive performance effects on the local firm than domestic institutions, in particular in emerging market economies. For example, foreign investors based in developed market economies may provide local firms in their portfolio with access to a larger, global pool of financial resources compared to domestic institutions that mainly operate in the national capital markets (Taylor, 1990). Foreign investors may have a wealth of experience dealing with managerial opportunism and associated principal-agent problems in various national and cultural settings. This may make them better and more experienced monitors than domestically-oriented investors (Thomsen \& Pedersen, 2000). In addition, different investment preferences held by foreign institutional investors combined with their global investment experience may provide their investor firms with access to strategic expertise and knowledge that help them to gain a competitive edge compared to companies funded by domestic investors, especially when expanding internationally (Tihanyi et al., 2003). Following the increasingly international activity of the Taiwan Stock Exchange in the early 1990s foreign financial institutions are increasingly investing in Taiwanese listed firms, and domestic and foreign institutions may have a different impact on local firms.

Building on this research, we suggest:

H.3a. In Taiwan, the share ownership of foreign institutional investors has a stronger, positive association with performance than does ownership of domestic financial institutions.

H.3b. In Taiwan, the share ownership of investment funds has a stronger, positive association with performance than does ownership of banks.

\section{The governance effect of boards}

The previous discussion links firm's performance with the presence of large-block shareholders, such as family owners and outside institutional investors. However, this combination of different large-block holders may create its own problems. For example, cultivating trust between insiders and outsiders in a family-controlled business is difficult as owners are reluctant to share information they consider proprietary (Schulze et al., 2001). Paternalism also contributes to the highly centralised decision-making structure, concentrating power and control among people with family links to the owners of family firms (Daily \& Dalton, 1992). Having the initial human capital deriving from family members, there is a tendency for owners' entrenchment as managers in their firms (Gomes-Mejia et al., 2003 GomesMejia, Nunez-Nickel, \& Guttierrez, 2001). Although family and institutional ownership concentration overcomes some of the agency costs associated with lack of legal protection of minority shareholders, other, complementary governance mechanisms are needed to deal with possible entrenchment of dominant owners (Anderson \& Reeb, 2003, 2004; Rediker \& Seth, 1995). In this section, we focus on governance and strategy functions of boards in Taiwanese firms. 
Corporate governance research and organization studies increasingly recognise that boards of directors have a central role in reducing agency problems, and board structure and characteristics may influence strategic choices (Zahra \& Pearce, 1989). The resource dependence and strategic change perspectives have suggested that, in addition to control functions, the board may also play service/resource and strategic roles in the decision-making process (Pfeffer, 1972; Daily, Johnson, \& Dalton, 1999). Effective monitoring and service roles are usually a function of structural factors such as the proportion of independent directors on the board, CEO/Chairman roles held jointly or separately, etc. (Daily et al., 1999; Zahra \& Pearce, 1989; Young, Ahlstrom, Bruton, \& Chan, 2001). Finally, institutional theorists suggest that board independence may be used as a signalling device by organizations that act to enhance or protect their legitimacy, especially in the investor community (North, 1990; Peng, 2004).

A number of studies try to link board characteristics directly to firm performance. Brickley, Coles, J., and Terry (1994) discuss the governance impact of alternative board composition by examining whether boards with a higher percentage of independent members from outside the firm are associated with greater valuation. Similarly, Xie, Davidson III, \& DaDalt (2002) test the effect of independent boards of directors in preventing the manipulation of earnings statements. Results suggest that independent board and audit members, especially those with appropriate areas of expertise, effectively lower the discretionary current accruals shown in corporate financial reports. However, there is a paucity of studies of governance effects of corporate boards outside the US. For example, Authur (2001) uses 135 firms from the Australian Stock Exchange in 1989 and Mak and Li (2001) use 147 Singaporean listed companies, both of which find empirical support for the view that managerial influence can bias board composition towards appointing board members that are allies of the CEO. In his study of boards of the largest firms in China Peng (2004) documents a positive relationship between presence of independent directors and firm performance.

Specific characteristics of corporate boards in large Taiwanese firms bring new and interesting dimensions to this research on governance roles of boards. Existing studies on corporate governance in family-controlled firms in South and East Asia and our account of institutional aspects of corporate sector in Taiwan provided above suggest that family members dominate the boards of directors (Bruton et al., 2003; Young et al., 2001). Management is exercised through a senior owner-manager who typically assumes the presidency of the firm and concurrently holds the top executive position and therefore, has complete control of the firm and its decisions (Carney \& Gadajlovic, 2003). In this environment, agency analysis of performance outcomes of board independence from the CEO and other executives that dominated research in the USA and other developed economies becomes less relevant. Instead, research focus shifts towards studying organizational outcomes of directors' independence from controlling families (Carney \& Gadajlovic, 2002; Gomes-Mejia et al., 2003).

On one hand, our previous arguments suggest that, in Taiwan, family control may be associated with better performance. Therefore, the appointment of 'controllers' that are related to the largest family may re-enforce positive effects of family ownership. On the other hand, this family control over boards may lead to greater executive entrenchment and potential conflicts with outside investors, in particular with institutional shareholders whose 
strategy preferences may differ from the family interests (Anderson et al., 2003; GomezMejia et al., 2001). For example, Schulze, Lubatkin, \& Dino (2003) suggest that altruism can bias the CEOs' perceptions of their relatives employed on the board, which hampers their ability to monitor and discipline them. Wiseman and Gomes-Mejia (1998) argue that family-related directors face higher exit costs because leaving the firm would mean forgoing certain rights, perquisites and privileges associated with being part of the controlling family. These high exit costs translate into a higher level of entrenchment. Given an emphasis in the literature on the links between controlling coalitions of large block shareholders and the effectiveness of the board, it is possible to suggest that non-family directors may have an important governance role that is complementary to monitoring by large-block holders in terms of reconciling potentially different interests of the family and outside investors and leading to more efficient organizational outcomes.

In addition to the agency approach to the roles of corporate boards, Peng (2004) and Young et al. (2001) develop resource-based and institutional arguments suggesting that non-family directors may have positive effect on performance in emerging markets. Bearing in mind the importance of networks in South and East Asian economies, non-family directors may provide additional external ties that can be used to access resources and knowledge that are more diverse than resources of the controlling family (Filatotchev \& Bishop, 2002). In addition, new organizational practices, including appointing outside directors, represent important means to enhance or protect organizational legitimacy and to keep up with competition (Peng, 2004: 458). These resource and institutional arguments suggest that presence of non-family directors improve competitive position of the firm. Thus:

H.4. In Taiwan, the extent of board independence from the controlling families is positively associated with performance.

Finally, mandatory share ownership of board members in Taiwan provides a unique opportunity to analyse performance outcomes of directors' financial interest beyond the traditional research focus of the possible effects of equity-based incentives in the West. Although independent directors may provide a particularly important strategic contribution by a direct involvement in developing strategy, the research literature on corporate boards suggests that board involvement in policy-making is often passive, and it relies mainly on financial outcomes of strategic decisions of the CEO (Baysinger \& Butler, 1985; Golden \& Zajac, 2001). However, when an organization encounters uncertain environmental conditions, or is in its growth phase, the board of directors needs to be more pro-active in terms of its involvement in decision-making. The board should also be able to shift emphasis from financial control and evaluation of managerial decisions to strategic control more focused on longer-term organizational outcomes (Baysinger \& Hoskisson, 1990). Therefore, independent directors need to have strong incentives to perform monitoring, resource and service functions effectively.

Previous research links close involvement in strategy development and implementation with the personal financial risk approximated by ownership interests in the firm (Oswald \& Jahera, 1991; Shivdasani \& Yermack, 1999). Geletkanycz, Boyd, and Finkelstein (2001) associate board ownership with strategic power, whereas Hambrick and Jackson (2000) indicate that share ownership not only creates financial incentives for independent directors 
but also increases their identification with the company, making them more vigilant in their oversight and more generous in their time and attention. Bearing in mind the mandatory requirement for board members to hold shares in listed firms in Taiwan, it is possible to suggest that these financial incentives may have a particularly strong effect in terms of aligning interests of families and external minority shareholders. These arguments imply that:

H5. In Taiwan, board members' share ownership is positively associated with performance.

\section{Data and methodology}

\section{Sample}

To test these hypotheses, data on all companies listed on the Taiwan Stock Exchange in 1999 was compiled. Of these, 25 financial institutions were excluded following common practice in the literature, (see, for example, Shivdasani \& Yermack (1999), Faccio \& Lasfer (2001), Kroszner \& Strahan (2001), Mitton (2002) and Singh and Davidson (2002)) given the nature of corporate governance in financial institutions differs from that in non-financial firms. The final sample is 228 public trading companies, distributed across the industry sectors as follows: Textiles (54), Construction (40), Electrical (54) and Services (36). The residual 44 companies are from the remaining sectors. All data were taken from reports submitted to the SFC.

\section{Measures}

Variables used are in four main groups: family and institutional ownership, board characteristics, measures of firm performance and control variables. Data on ownership is central to this study, and were obtained from the SFC. The use of ownership structure as a proxy for corporate governance varies considerably in the literature. Common to much research is a focus on the governance effect of management shareholding, generally using ownership with respect to board members (for example, Arthur, 2001; Mak \& Li, 2001), to the CEO (for example, Core, Holthausen, \& Lacker, 1999; Zhou, 2001), and to senior management, including managers and directors (for example, Himmelberg, Hubbard, \& Palia, 1999; Hanson and Song, 2000). However, given that large shareholders may be critical in studies of corporate governance, some authors specifically use the holdings of dominant shareholders as the ownership variable and test its effect on corporate value (for example, Demsetz, \& Lehn, 1985; Ang, Cole, \& Lin, 2000). Finally, others use a measure of outside block-holders as a proxy for the degree of monitoring activity (for example, Faccio, \& Lasfer, 2000; Singh, \& Davidson, 2002).

Given the high concentration of family owned firms in Taiwan, the measure of ownership is defined as the equity holding of the largest individual shareholder and close family. Following Claessens et al. (2000) and Chang (2003) the membership of the controlling family is identified by linking corporate insiders including CEO, board chairman, honorary chairman and vice chairman of the company that share a common family name with the 
largest owner. However, the five most common Chinese family names, Lin, Li, Chen, Chang and Wang, are also common in Taiwan and so this is not a sufficiently stringent criterion. Thus, family membership is identified as having one of these five names plus the first name of the largest shareholder from the male side of the family. Having identified the family of the largest shareholder, we investigate the shareholding of every individual member and sum these to define the total ownership of each family.

To capture the governance effect of different external block-holders, institutional investors are divided into financial institutions and non-financial corporate investors. Assuming that domestic and foreign institutions may have a different impact on monitoring activity, they are treated separately. Further, even amongst financial institutions, banks and investment trusts may behave differently, and these are also considered separately. In Taiwan, corporations are also among important institutional shareholders, and their share ownership needs to be controlled for. Thus, in addition to family ownership, we use five institutional ownership variables: domestic and foreign banks and domestic and foreign investment trusts and corporations.

Several variables are used to measure board characteristics, such as composition, size, shareholding and leadership. In terms of board composition, previous studies differentiate between "insider" directors (e.g., current and retired firm employees, their family members, etc.), "affiliate" directors (e.g., non-employee board members with business ties to the firm) and "independent" directors whose relations with the firm is restricted to their board membership only (see Anderson \& Reeb, 2004, for a discussion). However, in this study we are focused on the organizational outcomes of board members' direct family links with family-owners. Therefore, board independence from the family was operationalised using three variables. A dummy variable Independent Chairman denotes that the chairman is not from the family with the largest shareholding. In addition, \% Directors/Family and $\%$ Supervisors/Family are the percentages of total seats on the board of directors and the supervisors that is controlled by any relative of the firms' largest family owner, or any organization controlled by the member of this family, respectively. Board Share Holding is the total shareholding of the board of directors plus the supervisors.

A number of measures of firm performance are used in this study. The ratio of market to book value (MTBV) is the most common measure in empirical corporate governance research (see for example, Morck et al., 1988; McConnell, \& Servaes, 1990; Cho, 1998; Himmelberg et al., 1999). However, according to Chang, \& Hong (2000) a significant herding effect is found in Taiwan, and therefore pricing on the TSE is not fully efficient and may not sufficiently reflect the true value of the firm. Thus, two accounting measures are used here in addition to book-to-market ratio which have been widely used in previous research (see Demsetz, \& Lehn, 1985; Ang et al., 2000):

\section{Return on capital employed $($ ROCE $)=$ Profit before Tax/Total Issued Capital}

Return on assets $(\mathrm{ROA})=$ Profit before Interest/Total Assets

In addition to these accounting ratios, we used two capital and product market-based performance proxies. These measurements were sales revenue as the percentage of issued capital 
(STIC) and earning per share (EPS). The later was calculated as

EPS $=($ Profits after Tax-Dividend Paid on Preference Shares $) /$ Total Issued Shares

Control variables were used to account for industry effects and resource allocation factors. Industry dummies represent the four industrial categories: Textiles (clothes, natural and synthetic fibres, and plastic material), Construction (the construction industry plus material providers including cement, glass, and steel), Electrical (electrical machinery, electrical appliance, \& cables, computers and semiconductors) and Services (transport, tourism, wholesale and retail trading), with firms from the remaining industries used as control. Other controls include the logarithm of capital intensity ratio, the logarithm of number of employees, the logarithm of age of the firm, the gearing ratio, the profit margin and a dummy variable that defines whether the firm is a member of a bigger group and zero otherwise. Previous research on corporate governance effects on performance in emerging markets provides justification for inclusion of these control variables (see Bruton et al., 2003; Carney, \& Gedajlovic, 2003; Chang, \& Hong, 2003; Claessens et al., 2000; La Porta et al., 2000, for a discussion). Our analysis of board effects on performance also included as controls the logarithms of the size of the board of directors and the number of supervisors respectively.

Modelling the relationship between corporate governance factors and productivity has generally been approached through standard econometric techniques, such as regression analysis. The real problem revolves around the issue of endogeneity, and much of the robustness testing in this study is concerned with statistical procedures that investigate the existence of endogenous variables and correcting for this where it is found. This concern is noted in the literature (Demsetz, 1983; Demsetz, \& Lehn, 1985; Cho, 1998).

To address endogeneity problems we used two-stage least squared regression analysis and instrumental variables. To test for endogeneity in the model, the method of Generalised Instrumental Variable Estimation (GIVE) is used. Firstly, each of the potentially endogenous variables is individually regressed on a set of available instruments and the truly exogenous variables in the model. These represent a series of single reduced form or artificial equations, where the instruments are one and two period lagged values of the potentially endogenous variables. Then, the Wu-Hausman procedure is used to identify which variables are endogenous, correcting with the instruments where required. Finally, the Sargan-Basmann test provides a measure of the adequacy and effectiveness of these instrumental variables to solve the problem (see Chang, 2003, for a detailed discussion of this methodology).

\section{Results}

Table 2 provides the correlation matrix and descriptive statistics for the variables used in this study. In terms of the industry structure of our sample, $23 \%$ of companies belong to the textile industry, $17 \%$ are in construction, $23 \%$ are in the electrical and electronics industries, and about $16 \%$ companies are from the services sector. On average, sample firms employ 1330 employees, and the firms are approximately 31 years old. The average level of capitalisation of sample firms is NT\$ 544 million (approximately US\$ 15.5 million). 
Table 2. Mean, standard deviation and correlatons.

\begin{tabular}{|c|c|c|c|c|c|c|c|c|c|c|c|c|c|c|c|c|c|c|c|c|c|c|c|c|c|}
\hline $\begin{array}{l}\text { Varaiables } \\
\end{array}$ & Mean $S$. & S. Dev & 1 & 2 & 3 & 4 & 5 & 6 & 7 & 8 & 9 & 10 & 11 & 12 & 13 & 14 & 15 & 16 & 17 & 18 & 19 & 20 & 21 & 22 & 23 \\
\hline 1. Textiles Industry & 0.24 & 0.43 & - & & & & & & & & & & & & & & & & & & & & & & \\
\hline $\begin{array}{l}\text { 2. Construction } \\
\text { Industry }\end{array}$ & 0.18 & 0.38 & $-0.25^{* *}$ & & & & & & & & & & & & & & & & & & & & & & \\
\hline $\begin{array}{l}\text { 3. Electrics } \\
\text { Industry }\end{array}$ & 0.24 & 0.43 & $-0.31^{* *}$ & $-0.25^{* *}-$ & & & & & & & & & & & & & & & & & & & & & \\
\hline 4. Services Industry & 0.16 & 0.37 & $-0.24^{* *}$ & $-0.20^{* *}-$ & $-2.24^{* *}-$ & & & & & & & & & & & & & & & & & & & & \\
\hline 5. In Capital-labor ratio & 15.36 & 0.90 & -0.03 & $0.42^{* *}$ & $-0.26^{* *}-$ & -0.08 & - & & & & & & & & & & & & & & & & & & \\
\hline $\begin{array}{l}\text { 6. In Number of } \\
\text { Employee }\end{array}$ & 6.58 & 1.10 & 0.02 & $-0.19^{4 *}$ & $0.26^{* *}$ & -0.10 & -0.60 & - & & & & & & & & & & & & & & & & & \\
\hline 7. In Age & 3.37 & 0.35 & 0.09 & -0.01 & $-0.31^{* *}$ & 0.01 & -0.03 & 0.13 & - & & & & & & & & & & & & & & & & \\
\hline $\begin{array}{l}\text { 8. Bussiness Group } \\
\text { Affilation }\end{array}$ & 0.36 & 0.48 & 0.11 & $-0.13^{3^{* *}}$ & 0.07 & 0.02 & 0.04 & $0.26^{* *}$ & -0.02 & - & & & & & & & & & & & & & & & \\
\hline 9. Gearning Ratio & 0.76 & 0.48 & -0.09 & $0.16^{*}$ & 0.06 & -0.07 & 0.05 & 0.08 & 0.07 & 0.03 & - & & & & & & & & & & & & & & \\
\hline 10. Profit Margin & 5.1816 & $16.63-7=0$ & -0.07 & $-0.18^{*}$ & 0.09 & $0.16^{*}$ & $-0.18^{* *}$ & $0.22^{2 *}$ & 0.02 & $0.18^{* *}$ & $-0.26^{* *}-$ & & & & & & & & & & & & & & \\
\hline $\begin{array}{l}\text { 11. Instititutional } \\
\text { Investors' Ownership }\end{array}$ & 5.34 & 4.87 & -0.08 & -0.11 & $0.29^{* *}$ & -0.09 & 0.02 & $0.24^{* *}$ & -0.05 & $0.20^{* *}$ & -0.07 & $0.20^{* *}-$ & & & & & & & & & & & & & \\
\hline 12. corporate Ownership & 18.631 & 11.68 & 0.01 & 0.10 & $-0.23^{* *}$ & $0.13^{*}$ & $0.23^{* *}-$ & $-0.13^{*}$ & 0.02 & $0.24^{* *}$ & $0.14^{*}$ & $-0.02-$ & -0.02 & - & & & & & & & & & & & \\
\hline 13. Family Onwership & 17.231 & 13.00 & 0.08 & -0.09 & $-0.21^{* *}$ & $0.21^{* *}$ & -0.01 & 0.01 & 0.06 & $0.27^{* *}$ & -0.05 & $0.18^{* *}-$ & -0.05 & $0.23^{* *}$ & & & & & & & & & & & \\
\hline 14. Indep. Chariman & 0.23 & 0.42 & -0.01 & 0.02 & $0.16^{*}-$ & -0.03 & 0.09 & 0.02 & -0.06 & 0.04 & -0.07 & 0.06 & $0.06-$ & -0.05 & $-0.30^{* *}$ & & & & & & & & & & \\
\hline $\begin{array}{l}\text { 15. In Size Executive } \\
\text { Board }\end{array}$ & 1.98 & 0.49 & -0.01 & 0.02 & 0.03 & -0.09 & 0.05 & $0.29^{* *}$ & $0.26^{* *}$ & $0.21^{* *}$ & 0.05 & 0.10 & $0.15^{*}$ & 0.03 & -0.08 & $0.22^{2 *}$ & & & & & & & & & \\
\hline $\begin{array}{l}\text { 16. In size Supervisory } \\
\text { Board }\end{array}$ & 0.61 & 0.48 & -0.12 & 0.05 & $0.15^{*}$ & $-0.13^{*}$ & 0.08 & $0.20^{* *}$ & 0.06 & $0.26^{* *}$ & -0.06 & 0.13 & $0.21^{1 * *}$ & 0.08 & -0.07 & $0.21^{* *}$ & $0.58^{* *}$ & & & & & & & & \\
\hline $\begin{array}{l}\text { 17. \% Directors linked } \\
\text { to Family }\end{array}$ & 46.882 & 27.44 & $0.15^{*}$ & -0.06 & $-0.30^{* *}$ & 0.11 & 0.06 & -0.10 & $0.15^{*}$ & 0.03 & 0.00 & $-0.02-$ & -0.09 & $0.17^{*}$ & $0.45^{5 *}$ & $-0.42^{* *}$ & $-0.31^{1 * *}$ & $-0.25^{* *}-$ & & & & & & & \\
\hline $\begin{array}{l}\text { 18. \% Supervisors } \\
\text { linked to Family }\end{array}$ & 42.0240 & 40.83 & $0.20^{* *}$ & -0.04 & $-0.27^{7^{*}}$ & 0.12 & 0.10 & -0.10 & $0.18^{* *}$ & 0.12 & 0.05 & -0.05 & -0.04 & $0.23^{* *}$ & $0.44^{* *}-$ & $-0.22^{2 *}$ & $-0.17^{*}$ & $-0.24^{* *}$ & $0.62^{* *}-$ & & & & & & \\
\hline 19. Boards' & 20.6712 & $12.48-$ & -0.05 & -0.06 & -0.11 & $0.28^{* *}$ & -0.07 & 0.01 & -0.08 & 0.09 & -0.08 & $0.21^{* *}-$ & -0.05 & $0.17^{*}$ & $0.57^{* *}-$ & -0.10 & 0.00 & 0.03 & 0.13 & $0.17^{*}$ & - & & & & \\
\hline $\begin{array}{l}\text { Shareholding } \\
\text { 20. RIA }\end{array}$ & 2.79 & 7.27 & -0.06 & -0.12 & $0.19^{* *}$ & -0.03 & -0.06 & $0.18^{* *}$ & -0.04 & $0.17^{*}$ & $-0.19^{* *}$ & $0.36^{* *}$ & $0.27^{* *}$ & -0.02 & 0.09 & 0.07 & 0.07 & $0.19^{9 * *}$ & 0.11 & -0.04 & $0.22^{* *}$ & - & & & \\
\hline 21. ROCE & 4.8718 & 18.74 & -0.10 & -0.10 & $0.19^{9 * *}$ & 0.01 & -0.09 & $0.18^{* *}$ & -0.06 & $0.16^{*}$ & $-0.24^{* *}$ & $0.40^{* *}$ & $0.29^{* *}$ & -0.04 & 0.09 & 0.06 & 0.06 & $0.18^{*}$ & $-0.14^{*}$ & -0.09 & $0.24^{* *} 0$ & $0.92^{* *}$ & & & \\
\hline 22. MTBV & 0.88 & 0.98 & $-0.15^{*}$ & $-0.20^{* *}$ & $0.40^{* *}$ & 0.02 & $-0.18^{* *}$ & $0.23^{* *}$ & $-0.30^{0 *}$ & 0.04 & -0.10 & $0.20^{* *}$ & $0.34^{* *}-$ & -0.11 & 0.04 & 0.08 & -0.05 & $0.14^{*}$ & $-0.20^{*}$ & $-0.15^{* *}$ & $0.14^{* *} 0$ & $0.47^{*}$ & $0.52^{*}$ & & \\
\hline 23. STIC & 5.2311 & 10.39 & $-0.15^{*}$ & -0.07 & $0.13^{*}$ & 0.00 & $-0.16^{*}$ & $0.19^{* *}$ & $-0.14^{*}$ & 0.01 & $-0.18^{* *}$ & $0.25^{* *}$ & $0.24^{* *}$ & 0.01 & $0.01-$ & -0.04 & 0.01 & $0.13^{*}$ & $-0.19^{* *}$ & 0.10 & $\begin{array}{lll}0.16^{*} & 0\end{array}$ & $0.63^{* *}$ & & $0.59^{* *}$ & \\
\hline 24. EPS & 0.55 & 2.42 & -0.08 & -0.02 & $0.16^{*}$ & -0.04 & -0.02 & $0.2^{5 *}$ & -0.08 & 0.08 & $-0.36^{* *}$ & $0.42^{* *}$ & $0.22^{* *}-$ & -0.04 & 0.00 & 0.07 & 0.07 & $0.19^{* *}-1$ & $-0.12-1$ & $\begin{array}{ll}-0.08 & 0\end{array}$ & $0.26^{* *} 0.8$ & $0.80^{* *} 0$ & $0.82^{* *} 0$ & $49^{* *} 0.63$ & $63^{* *}$ \\
\hline
\end{tabular}

${ }^{* *}$ Correlation is significant at the 0.01 level (two-tailed); ${ }^{*}$ Correction is significant at the 0.05 level (two-tailed). 
In terms of ownership structure, equity stakes of financial institutions and non-financial corporate investors are 5.3 and 18.6 percent respectively. On average, controlling families hold $17.2 \%$ of the firms' equity, and more than a third of firms are members of wider family group networks. The sample characteristics are very close to the findings reported by Claessens et al. (2000) for a sample of 120 Taiwanese firms. We also verified the distribution of family ownership concentration, and our findings (not reported in Table 2) suggest that families with shareholding between 5-15\%, 15-25\% and 25-35\% control 33, 17.9 and $10.9 \%$ of firms in our sample respectively. Finally, almost $11 \%$ of companies are controlled by families with an equity stake over $35 \%$. Therefore, even compared with other Asian countries, the percentage of family controlled companies in Taiwan is extremely high. According to Claessens et al. (2000), out of nine Asian countries only Indonesia and South Korea have similar levels of family control. In other words, Taiwanese firms represent an interesting hybrid of Western and Asian corporate governance models, with a combination of family control and minority shareholders.

In terms of general board characteristics, only $23 \%$ of firms in our sample have an independent board chairman, that is, someone who is not related to the founding family. At the same time, the family shareholders control on average 46.8 and $42.02 \%$ of seats on executive boards or are supervisors respectively. The average board shareholding in our sample is $20.67 \%$.

Tables 3-5 report results of our formal tests of the stated hypotheses. First, we used 2SLS analysis to verify ownership effects on performance. According to the Wu-Hausman test, our ownership variables should be considered as endogenous, and we replaced direct measurements by instruments. Table 3 clearly shows that the combined ownership level of financial institutional investors is positively associated with all performance measurements, and these results support hypothesis 2 .

As Table 3 indicates, there is no significant effect of the family ownership instrument on all measurements of performance. To explore this issue further and test for a possible non-linearity in this relationship, we used piecewise linear regressions using three dummies for family ownership, having first divided the variable into three intervals, 5-15\%, 15-25\% and $25-35 \%$ (see Joh (2003) for a discussion of this methodology). None of these dummies had a significant coefficient. Overall, hypothesis 1 is not supported.

To verify possible differences in governance effects of various types of institutional investors (Tihanyi et al., 2003; Hoskisson et al., 2002) we introduced separate ownership variables for domestic and foreign banks and investment institutions in the regressions reported in Table 4 . The results clearly show that positive effects of institutional shareholders on performance are mainly driven by investment funds. However, foreign investment banks although have positive and significant effect on return on capital and market-to-book ratios. The effects of domestic banks are positive but insignificant. These results are in line with hypotheses $3 \mathrm{a}$ and $3 \mathrm{~b}$ that suggests different effects of various types of institutional investors on performance.

To verify the robustness of our analysis to the model specification, we used dummies for firms controlled by the state, foreign investors and family respectively. To identify the controlling shareholder, the largest shareholder was noted first, and if the largest corporate shareholder was an organization, an attempt was made to identify the individual owners 
Table 3. 2SLS regression analysis of ownership effects on performance.

\begin{tabular}{|c|c|c|c|c|c|}
\hline & ROCE & ROA & MTBV & STIC & EPS \\
\hline \multirow[t]{2}{*}{ Textile industry } & -0.08 & -0.05 & -0.06 & $-5.36^{* *}$ & -0.46 \\
\hline & $(3.41)$ & (1.36) & $(0.17)$ & (1.97) & $(0.42)$ \\
\hline \multirow[t]{2}{*}{ Construction industry } & 0.03 & -0.03 & -0.06 & -1.74 & 0.73 \\
\hline & $(3.95)$ & $(1.57)$ & $(0.20)$ & $(2.21)$ & $(0.47)$ \\
\hline \multirow[t]{2}{*}{ Electric industry } & 0.10 & 0.12 & $0.26^{* *}$ & -1.91 & 0.25 \\
\hline & $(3.85)$ & $(1.53)$ & $(0.20)$ & $(2.16)$ & $(0.46)$ \\
\hline \multirow[t]{2}{*}{ Service industry } & -0.05 & -0.07 & 0.05 & -2.94 & -0.41 \\
\hline & $(3.82)$ & $(1.52)$ & $(0.20)$ & $(2.18)$ & $(0.47)$ \\
\hline \multirow[t]{2}{*}{ Ln Capital-Labor Ratio } & 0.00 & 0.07 & 0.00 & -0.12 & -0.07 \\
\hline & $(1.86)$ & $(0.74)$ & $(0.10)$ & $(0.26)$ & $(0.06)$ \\
\hline \multirow[t]{2}{*}{ Ln Number of Employee } & 0.10 & 0.13 & $0.20^{*}$ & $2.24^{* * *}$ & $0.43^{* * *}$ \\
\hline & $(1.48)$ & $(0.59)$ & & & \\
\hline \multirow[t]{2}{*}{ Ln Age } & -0.01 & 0.02 & & & \\
\hline & $(3.46)$ & $(1.37)$ & & & \\
\hline \multirow[t]{2}{*}{ Business group affiliation } & 0.05 & 0.04 & & & \\
\hline & $(2.66)$ & (1.06) & & & \\
\hline \multirow[t]{2}{*}{ Gearing ratio } & $-0.19^{* *}$ & $-0.15^{*}$ & & & \\
\hline & $(2.46)$ & $(0.98)$ & $(0.13)$ & $(1.11)$ & $(0.24)$ \\
\hline \multirow[t]{2}{*}{ Profit margin } & $0.29^{* * *}$ & $0.26^{* * *}$ & $(0.08)$ & $\left(0.64^{4}\right)$ & $\left(0:(12)^{* * *}\right.$ \\
\hline & $(0.07)$ & $(0.03)$ & $-(0 . \oplus \Theta)^{*}$ & $-(0.08 *)^{*}$ & $-(0: 06)$ \\
\hline \multirow[t]{2}{*}{ Corporate ownership } & 0.03 & 0.05 & $(0 . \oplus \$)$ & $(0.07)$ & $(0: 02)$ \\
\hline & $(0.10)$ & $(0.04)$ & $-(0, \oplus Q)$ & $-\left(0.674^{\dagger}\right)$ & $-(0, \oplus 1)$ \\
\hline \multirow[t]{2}{*}{ Family ownership IV. } & 0.07 & 0.08 & $(0: \$ 4)$ & $(\emptyset: \theta 7)$ & $(0: 3 \overline{8})$ \\
\hline & $(0.09)$ & $(0.03)$ & $-(0.08)$ & $-(0.05)^{*}$ & $-(\Phi, \oplus 4)^{* *}$ \\
\hline \multirow[t]{2}{*}{ Institutional investors' ownership IV. } & $0.18^{* *}$ & $0.16^{*}$ & $0.23^{* * *}$ & $0.30^{* * *}$ & $0.05^{* *}$ \\
\hline & $(0.23)$ & $(0.09)$ & $(0.01)$ & $(0.08)$ & $(0.02)$ \\
\hline Adjusted $R$ square & 0.23 & 0.19 & 0.26 & 0.16 & 0.29 \\
\hline ANOVA $F$-value df $(13,214)$ & $6.19^{* * *}$ & $5.09^{* * *}$ & $7.30^{* * *}$ & $4.71^{* *}$ & $8.85^{* * *}$ \\
\hline
\end{tabular}

Note: All coefficients are standardised; ${ }^{\dagger} \leq 0.10 ;{ }_{p}^{*} \leq 0.05,{ }^{* *} p \leq 0.01 ;{ }^{* * *} p \leq 0.001$; standard errors in parentheses; IVs are instrumental variables; ANOVA $F$-value: Degree of Freedom (Regression, Residual).

of that organization. Where these exist, the ultimate owner and family links were checked, and family control is defined using the methodology suggested by La Porta et al. (1999) and Claessens et al. (2000). If this was not the case, we checked whether the controlling organization is a government institute or foreign organization. The regression coefficients for the family control dummy were significant in the regressions for accounting measures of 
Table 4. 2SLS regression analysis of ownership effects on performance for different categories of institutional investors.

\begin{tabular}{|c|c|c|c|c|c|}
\hline & ROOE & ROA & MTBV & STIC & EPS \\
\hline \multirow[t]{2}{*}{ Textile industry } & -0.07 & -0.04 & -0.04 & $-5.55^{* *}$ & -0.46 \\
\hline & {$[3.42]$} & {$[1.36]$} & {$[0.17]$} & [1.99] & {$[0.43]$} \\
\hline \multirow[t]{2}{*}{ Construction industry } & 0.04 & -0.01 & -0.05 & -1.45 & 0.73 \\
\hline & {$[3.98]$} & [1.59] & {$[0.20]$} & {$[2.23]$} & {$[0.48]$} \\
\hline \multirow[t]{2}{*}{ Electric industry } & 0.08 & 0.11 & $0.22^{*}$ & -1.70 & 0.25 \\
\hline & [3.89] & {$[1.55]$} & {$[0.20]$} & {$[2.19]$} & {$[0.47]$} \\
\hline \multirow[t]{2}{*}{ Service industry } & -0.03 & -0.05 & 0.08 & -2.60 & -0.41 \\
\hline & {$[3.97]$} & {$[1.58]$} & {$[0.20]$} & {$[2.23]$} & {$[0.48]$} \\
\hline \multirow[t]{2}{*}{ Ln Capital-Labor Ratio } & -0.01 & 0.08 & -0.01 & -0.14 & -0.06 \\
\hline & {$[1.90]$} & {$[0.76]$} & {$[0.10]$} & {$[0.26]$} & {$[0.06]$} \\
\hline \multirow[t]{2}{*}{ Ln Number of Employee } & 0.09 & 0.12 & $0.17^{*}$ & $2.21^{* * *}$ & $0.43^{* * *}$ \\
\hline & {$[1.49]$} & {$[0.6]$} & {$[0.08]$} & {$[0.56]$} & {$[0.12]$} \\
\hline \multirow[t]{2}{*}{ Ln Age } & 0.00 & 0.03 & $-0.14^{*}$ & $-0.17^{*}$ & -0.02 \\
\hline & {$[3.51]$} & {$[1.40]$} & {$[0.18]$} & {$[0.07]$} & {$[0.02]$} \\
\hline \multirow[t]{2}{*}{ Business group affiliation } & 0.05 & 0.04 & -0.09 & $-2.53^{\dagger}$ & -0.17 \\
\hline & {$[2.67]$} & {$[1.07]$} & {$[0.13]$} & [1.49] & {$[0.32]$} \\
\hline \multirow[t]{2}{*}{ Gearing ratio } & $-0.19^{* *}$ & $-0.15^{*}$ & -0.07 & $-2.23^{*}$ & $-1.14^{* * *}$ \\
\hline & {$[2.47]$} & {$[0.98]$} & {$[0.12]$} & {$[1.11]$} & {$[0.24]$} \\
\hline \multirow[t]{2}{*}{ Profit margin } & $0.29^{* * *}$ & $0.26^{* * *}$ & 0.08 & $0.04^{\dagger}$ & $0.02^{* * *}$ \\
\hline & {$[0.07]$} & {$[0.03]$} & {$[0.00]$} & {$[0.02]$} & {$[0.00]$} \\
\hline \multirow[t]{2}{*}{ Foreign funds ownership IV. } & $0.12^{\dagger}$ & 0.08 & $0.18^{* *}$ & $0.27^{*}$ & $0.05^{*}$ \\
\hline & {$[0.41]$} & {$[0.17]$} & {$[0.02]$} & {$[0.12]$} & {$[0.03]$} \\
\hline \multirow[t]{2}{*}{ Foreign Banks' Ownership IV. } & $0.11^{\dagger}$ & 0.08 & $0.17^{* *}$ & 0.21 & 0.05 \\
\hline & {$[1.09]$} & {$[0.43]$} & {$[0.05]$} & {$[0.23]$} & {$[0.05]$} \\
\hline \multirow[t]{2}{*}{ Domestic Banks' Ownership } & 0.03 & 0.03 & 0.01 & 0.20 & 0.05 \\
\hline & {$[0.38]$} & {$[0.15]$} & {$[0.02]$} & {$[0.21]$} & {$[0.05]$} \\
\hline \multirow[t]{2}{*}{ Domestic Funds' Ownership IV. } & 0.11 & $0.13^{\dagger}$ & $0.12^{\dagger}$ & $0.51^{*}$ & 0.05 \\
\hline & {$[0.70]$} & {$[0.28]$} & {$[0.04]$} & {$[0.21]$} & {$[0.04]$} \\
\hline \multirow[t]{2}{*}{ Corporate Ownership } & 0.02 & 0.05 & 0.00 & 0.07 & 0.01 \\
\hline & {$[0.10]$} & {$[0.04]$} & {$[0.01]$} & {$[0.04]$} & {$[0.01]$} \\
\hline \multirow[t]{2}{*}{ Family Ownership IV. } & 0.06 & 0.08 & 0.04 & 0.01 & 0.00 \\
\hline & {$[0.09]$} & {$[0.03]$} & {$[0.00]$} & {$[0.05]$} & {$[0.01]$} \\
\hline Adjusted $R$ square & 0.23 & 0.19 & 0.29 & 0.16 & 0.28 \\
\hline ANOVA $F$-value df $(16,211)$ & $5.26^{* * *}$ & $4.26^{* * *}$ & $6.70^{* * *}$ & $3.83^{* * *}$ & $6.98^{* * *}$ \\
\hline
\end{tabular}

Note: All coefficients are standardised; ${ }_{p} \leq 0.10 ;{ }^{*} p \leq 0.05,{ }^{* *} p \leq 0.01 ;{ }^{* * *} p \leq 0.001$; standard errors in parentheses; IVs are instrumental variables; ANOVA F-value: Degree of Freedom (Regression, Residual). 
Table 5. OLS regression analysis of board characteristics effects on performance.

\begin{tabular}{|c|c|c|c|c|c|}
\hline & ROCE & ROA & MTBV & STIC & EPS \\
\hline Textile industry & $\begin{array}{r}-0.06 \\
(3.12)\end{array}$ & $\begin{array}{r}-0.03 \\
(1.28)\end{array}$ & $\begin{array}{c}0.00 \\
(0.28)\end{array}$ & $\begin{array}{r}-4.13^{*} \\
(2.02)\end{array}$ & $\begin{array}{r}-0.29 \\
(0.43)\end{array}$ \\
\hline Construction industry & $\begin{array}{c}0.01 \\
(3.52)\end{array}$ & $\begin{array}{r}-0.04 \\
(1.44)\end{array}$ & $\begin{array}{r}-0.15^{*} \\
(0.32)\end{array}$ & $\begin{array}{c}-2.49 \\
(2.23)\end{array}$ & $\begin{array}{c}0.63 \\
(0.48)\end{array}$ \\
\hline Electric industry & $\begin{array}{c}0.13 \\
(3.42)\end{array}$ & $\begin{array}{c}0.13 \\
(1.40)\end{array}$ & $\begin{array}{l}0.34^{* * *} \\
(0.31)\end{array}$ & $\begin{array}{r}-2.18 \\
(2.18)\end{array}$ & $\begin{array}{c}0.34 \\
(0.47)\end{array}$ \\
\hline Service industry & $\begin{array}{r}-0.02 \\
(3.48)\end{array}$ & $\begin{array}{r}-0.05 \\
(1.43)\end{array}$ & $\begin{array}{c}0.04 \\
(0.31)\end{array}$ & $\begin{array}{r}-2.17 \\
(2.24)\end{array}$ & $\begin{array}{r}-0.55 \\
(0.48)\end{array}$ \\
\hline Ln Capital-Labor Ratio & $\begin{array}{c}0.14^{\dagger} \\
(1.67)\end{array}$ & $\begin{array}{c}0.19^{*} \\
(0.68)\end{array}$ & $\begin{array}{c}0.16^{\dagger} \\
(0.15)\end{array}$ & $\begin{array}{c}0.26 \\
(0.27)\end{array}$ & $\begin{array}{r}-0.06 \\
(0.06)\end{array}$ \\
\hline Ln Number of Employee & $\begin{array}{c}0.18^{*} \\
(1.35)\end{array}$ & $\begin{array}{c}0.20^{*} \\
(0.56)\end{array}$ & $\begin{array}{l}0.25^{* * *} \\
(0.12)\end{array}$ & $\begin{array}{l}1.90^{* * *} \\
(0.57)\end{array}$ & $\begin{array}{l}0.34^{* *} \\
(0.12)\end{array}$ \\
\hline Ln Age & $\begin{array}{c}0.03 \\
(3.27)\end{array}$ & $\begin{array}{c}0.04 \\
(1.34)\end{array}$ & $\begin{array}{r}-0.16^{*} \\
(0.29)\end{array}$ & $\begin{array}{r}-0.15^{*} \\
(0.08)\end{array}$ & $\begin{array}{r}-0.02 \\
(0.02)\end{array}$ \\
\hline Business Group Affiliation & $\begin{array}{c}0.04 \\
(2.33)\end{array}$ & $\begin{array}{c}0.04 \\
(0.96)\end{array}$ & $\begin{array}{r}-0.09 \\
(0.21)\end{array}$ & $\begin{array}{r}-1.80 \\
(1.47)\end{array}$ & $\begin{array}{r}-0.17 \\
(0.31)\end{array}$ \\
\hline Gearing ratio & $\begin{array}{c}-0.35^{* * *} \\
(1.70)\end{array}$ & $\begin{array}{c}-0.29^{* * *} \\
(0.70)\end{array}$ & $\begin{array}{r}-0.03 \\
(0.15)\end{array}$ & $\begin{array}{r}-1.58 \\
(1.11)\end{array}$ & $\begin{array}{c}-1.03^{\text {*** }} \\
(0.24)\end{array}$ \\
\hline Profit margin & $\begin{array}{l}0.30^{* * *} \\
(0.03)\end{array}$ & $\begin{array}{l}0.29^{* * *} \\
(0.01)\end{array}$ & $\begin{array}{c}0.10 \\
(0.00)\end{array}$ & $\begin{array}{c}0.05^{*} \\
(0.02)\end{array}$ & $\begin{array}{l}0.02^{* * *} \\
(0.00)\end{array}$ \\
\hline Independent chairman & $\begin{array}{r}-0.07 \\
(2.66)\end{array}$ & $\begin{array}{r}-0.04 \\
(1.09)\end{array}$ & $\begin{array}{r}-0.05 \\
(0.24)\end{array}$ & $\begin{array}{r}-3.86^{*} \\
(1.72)\end{array}$ & $\begin{array}{r}-0.12 \\
(0.37)\end{array}$ \\
\hline Ln size executive board & $\begin{array}{r}-0.10 \\
(2.82)\end{array}$ & $\begin{array}{r}-0.11 \\
(1.16)\end{array}$ & $\begin{array}{c}-0.21^{* *} \\
(0.25)\end{array}$ & $\begin{array}{r}-0.26 \\
(0.20)\end{array}$ & $\begin{array}{r}-0.01 \\
(0.04)\end{array}$ \\
\hline Ln size supervisory board & $\begin{array}{c}0.06 \\
(2.71)\end{array}$ & $\begin{array}{c}0.09 \\
(1.11)\end{array}$ & $\begin{array}{c}0.17^{*} \\
(0.24)\end{array}$ & $\begin{array}{r}1.46^{\dagger} \\
(0.83)\end{array}$ & $\begin{array}{c}0.20 \\
(0.18)\end{array}$ \\
\hline$\%$ Directors linked to family & $\begin{array}{r}-0.18^{*} \\
(0.05)\end{array}$ & $\begin{array}{r}-0.16^{*} \\
(0.02)\end{array}$ & $\begin{array}{r}-0.16^{\dagger} \\
(0.00)\end{array}$ & $\begin{array}{c}-0.11^{* * *} \\
(0.03)\end{array}$ & $\begin{array}{r}-0.01 \\
(0.01)\end{array}$ \\
\hline$\%$ Supervisors linked to family & $\begin{array}{c}0.04 \\
(0.03)\end{array}$ & $\begin{array}{c}0.09 \\
(0.01)\end{array}$ & $\begin{array}{c}0.06 \\
(0.00)\end{array}$ & $\begin{array}{c}0.03 \\
(0.02)\end{array}$ & $\begin{array}{c}0.00 \\
(0.00)\end{array}$ \\
\hline Boards' Ownership & $\begin{array}{l}0.18^{* *} \\
(0.09)\end{array}$ & $\begin{array}{l}0.17^{* *} \\
(0.04)\end{array}$ & $\begin{array}{c}0.08 \\
(0.01)\end{array}$ & $\begin{array}{c}0.08 \\
(0.06)\end{array}$ & $\begin{array}{l}0.04^{* *} \\
(0.01)\end{array}$ \\
\hline Adjusted $R$ square & 0.39 & 0.31 & 0.31 & 0.16 & 0.3 \\
\hline ANOVA $F$-value df $(16,211)$ & $9.97^{* * *}$ & $7.51^{* * *}$ & $7.27^{* * *}$ & $3.94^{* * *}$ & $7.36^{* * *}$ \\
\hline
\end{tabular}

Note: All coefficients are standardised; ${ }_{p} \leq 0.10 ;{ }_{p}^{*} \leq 0.05,{ }^{* *} p \leq 0.01 ;{ }^{* * *} p \leq 0.001$; standard errors in parentheses; ANOVA $F$-value: Degree of Freedom (Regression, Residual). 
performance. These results indicate that family ownership provides effects on performance only in terms of the control threshold, and further research on this issue is needed.

In further tests we also used interactions between the family control dummy and institutional share ownership. Interestingly, an interaction between share ownership of foreign institutional investors and the family control dummy provided a positive and highly significant effect on performance measurements. This suggests that foreign investors positively moderate the effects of family control, which provides some support to our theoretical assumptions about possible coalitions among the most important block-holders.

Finally, Table 5 provides test results with respect to the governance effects of board characteristics. In terms of board independence variables, an independent chairman provided a negative and significant effect on the sales-to-issued capital ratio only. However, the percentage of executive board members associated with the family is negatively related to all measurements of corporate performance. In our analysis, we introduced board seats separately for supervisors and executive boards, but the results for supervisors are insignificant for performance variables. In other words, family control of the executive board is detrimental for performance, but family-related chairman and supervisors do not seem to have effect on performance, and hypothesis 4 is only partially supported. Table 5 also shows that board directors' share ownership is positively associated with three performance proxies, in line with hypothesis 5 .

In terms of the possible effects of our control variables, the result of the OLS regressions show that the Taiwanese electrical companies are significantly associated with better corporate performance. By contrast, companies in traditional industries including textiles and construction are generally under-performing. Large, younger and capital-intensive firms are generally performing better as well. In terms of our financial controls, the level of gearing in Taiwanese firms has a negative impact on corporate value and this relation is strongly significant at $1 \%$ level except in the regressions for the market-to-book variable. Corporate profit margins are positively associated with firm value and this positive relation is only insignificant in the market-to-book model. Generally, this supports the main assumptions of the resource based view that firms with larger resource endowments will perform better (Teece, 1980).

\section{Discussion and conclusions}

Previous research on the effects of ownership structure and board characteristics on performance has been predominantly Western, and in particular, an Anglo-American concern. However, firms elsewhere, and especially in East Asia, operate with a distinctive culture and in different legal and institutional environments, which may have an important impact on governance-performance relationships suggested by agency and strategy research. Thus, the applicability of the Western models should be tested in different contextual environments, and in this paper we have examined inter-relationships between general governance factors and firm performance in family-controlled and publicly listed firms in Taiwan.

Contrary to the assumption of fast growing law and economics research (e.g., Claessens et al., 2000; La Porta et al., 1997, 1998, 2000) we did not find a direct association between family ownership and managerial entrenchment and extraction of the private benefits of 
control, which should be detrimental to financial performance. Recent corporate scandals such as Enron in the US have provided a new impetus to the debate about whether families or professional managers run companies better for society in general. These debates have resulted in a growing interest in the importance of the values prevalent in family-owned companies (Anderson et al., 2003; Anderson \& Reeb, 2003, 2004; Bruton et al., 2003; James, 1999). Our results contribute to these debates by providing empirical analysis of links between family control and performance in the specific institutional setting of Taiwan.

Although previous research provides ambiguous results in terms of the possible effects of external block-holders on performance (e.g., Maug, 1998; Pound, 1988; Short, 1994), our results confirm a positive and significant relationship between institutional share ownership and all performance proxies after controlling for possible endogeneity. These results are consistent with a block-holder coalition framework that suggests an incentive alignment effect of a coalition of large shareholders that reflects a positive relation between the cash flow stake of the controlling coalition and total firm value. In other words, the presence of institutional investors may provide an effective remedy to a principal-principal agency relationship in family-controlled firms (Young et al., 2002), especially in the absence of a market for corporate control (Agrawal \& Knoeber, 1996).

This paper also supports more recent studies that identify differences in corporate governance effects associated with different types of institutional shareholders. Previous research recognizes the different governance effects of various types of institutional investors (Tihanyi et al., 2003; Hoskisson et al., 2002). In particular, our findings emphasise the importance of foreign institutional investors in terms of performance outcomes. The process of globalization of Taiwanese capital markets may lead to good governance practices being imported by domestic firms, and future research on this issue may have very important implications for other emerging market economies that want to attract foreign investors. However, we did not find consistently significant, positive effects on performance proxies of equity held by foreign banks. Because of data limitations we cannot answer the question: Do foreign banks own shares for their own investment accounts, or are they holding shares on behalf of other institutional investors as custodial banks? If the latter, then the governance roles of foreign banks may be limited, and further research on this very important issue is in order.

Our research also provides evidence of selectivity in terms of the effects of various board characteristics on firm performance. Although previous research does not generate compelling evidence of positive outcomes of board independence (e.g., Brickley et al., 1994; Xie et al., 2002), our findings suggest that family control over the executive board is detrimental to performance. This finding, combined with a lack of evidence of family ownership effects on performance, suggests that board dominance may be another channel through which families may try to extract the private benefits of control. This aspect may develop further law and economics research that is mainly focused on private benefits associated with voting rights (La Porta et al., 1998, 2000a).

Our findings suggest that such an important board characteristic as the presence of an independent Chairman does not seem to affect performance. Considering that previous research was attempting to associate Chairman independence with more efficient monitoring and control of managerial discretion by focusing mainly on publicly owned organizations 
in the West, it is possible that in the context of Taiwan, connections and social capital may be of vital importance, and the removal of such an individual may have a negative impact on the firm (Bruton et al., 2003). Further research on this very important issue is in order. Finally, this study also represents an important step in our understanding of the financial dependence perspective (Hambrick \& Jackson, 2000) by providing strong evidence of links between the financial commitment of the board members and organizational performance.

Our paper makes a number of theoretical contributions to current corporate governance debates. More specifically, previous research has focused on separate organizational outcomes of family/insider owners, outside block-holders and board characteristics (Dalton et al., 2003; Daily et al., 2003; Gomez-Meija, 2003). Our arguments provide an integrated conceptual framework that brings together the analysis of simultaneous performance effects of various insider and outside investors, as well as their participation in corporate boards. Since alternative control mechanisms exist, an intensive use of one of them should not necessarily be associated with superior firm performance (Agrawal \& Knoeber, 1996). Therefore, this paper also contributes to previous studies suggesting that one governance channel may complement and/or substitute for another (Hoskisson et al., 2002). Rediker and Seth (1995), for example, emphasize that firm performance depends on the efficiency of a number of governance mechanisms, such as board independence, monitoring by large outside shareholders, and incentive effects of directors' shareholding. However, their research is focused on the roles of various governance mechanisms in mitigating principal-agent conflict associated with dispersed share ownership. This paper's arguments extend Rediker and Seth's analysis by focusing on governance roles of various block-holders, corporate boards and board equity interests in the context of an emerging market economy where legal, financial and economic institutions are different from the West. Our conceptual framework suggests that legal and institutional "voids" (Khanna \& Palepu, 1997, 2000) may potentially aggravate problems associated with a combination of principal-agent and principal-principal relationships. In this environment, complementarities between ownership- and board-related governance factors may be particularly important.

This study has several limitations that may suggest a number of avenues for future research. Firstly, although an initial attempt has been made to take into account possible endogeneity of share ownership when examining how large outside shareholders may affect the performance of Taiwanese firms, the retained share ownership provided a very crude measurement of their control. Therefore, a more refined analysis of possible effects of different groups of outside investors would be useful. Secondly, our arguments imply a positive, linear effect of family ownership on performance. A number of studies suggest that ownership concentration creates a trade-off between incentive alignment and entrenchment effects (Shleifer \& Vishny, 1997). Therefore, the question of whether family ownership hinders or facilitates firm performance becomes an empirical issue that is related to institutional and politico-regulatory factors (Anderson, \& Reeb, 2003). Moreover, the presence of this trade-off suggests that the relationship between ownership and firm performance may be non-linear. For example, in their study of S\&P 500 firms in the US, Anderson and Reeb (2003) find that performance is first increasing and then decreasing in ownership, indicating that when families have the greatest control of the firm, the potential for entrenchment and poor performance is the greatest. These factors combined may explain our non-findings in 
relation of family ownership effects on performance in Taiwan. Although we tried to control for non-linearity using piecewise regression analysis, further, more fine-grained analysis is in order. Thirdly, our arguments around performance outcomes of family ownership suggest that families may have a long-term horizon, and, as a result, different performance measurements may have different implications for family owners. Similarly, different institutional investors may have different time horizons, and, therefore, different preferences in terms of short- and long-term performance. Although our use of a wide range of performance proxies represents an improvement compared to previous studies in emerging markets (Filatotchev et al., 2000; Peng, 2004), an analysis of longer-term performance outcomes of different governance mechanisms is in order. Finally, it is important to verify board appointment mechanisms that are used by Taiwanese companies. More specifically, since external board members may be vetted and approved by the family or other dominant block-holders, what is the extent of their independence from the dominant owners? Since our focus was on direct, family links between board members and family-owners, we did not account for "affiliate" directors, i.e., non-family board members with business ties to the firm. Future analysis of the governance roles of these board members is important, although data availability constraints in Taiwan make this research difficult.

A number of extensions of this research can also be suggested. The increased scrutiny of board activities has come from not only academic research but also the regulators and business community. Most of the recommendations emerging from the corporate governance debate revolve around such issues as board structure and independence (Golden, \& Zajac, 2001). The findings of this study highlight the value of integrating institutional theory with agency research in the analysis of factors affecting board composition and share ownership. The next stage should be focused on efficiency outcomes of various combinations of board and ownership characteristics (Daily, \& Dalton, 1992). In a dynamic perspective, "positions of power will flow to groups best able to meet the critical problems and contingencies faced by the organization in its environment" (Ocasio, \& Kim, 1999: 539).

\section{Acknowledgments}

An earlier version of this paper was presented at the Strategic Management Society MiniConference on "Strategy Research in Emerging Economies" (Hong Kong, December 2003) and the 2004 Academy of International Business Annual Conference, (Stockholm, Sweden). We would like to thank Trevor Buck, Mike Peng, Roger Strange, Mike Wright, the Editor and two anonymous reviewers for many helpful ideas and comments.

\section{References}

Admati, A., Pfleiderer, P., \& Zechner, J. 1994. Large shareholder activism, risk sharing, and financial market equilibrium. Journal of Political Economy, 102: 1097-1130.

Agrawal, A., \& Knoeber, C. 1996. Firm performance and mechanisms to control agency problems between managers and shareholders. Journal of Financial and Quantitative Analysis, 31: 377-395.

Anderson, R., Mansi, S., \& Reeb, D. 2003. Founding family ownership and the agency costs of debt. Journal of Financial Economics, 68: 263-285. 
Anderson, R., \& Reeb, D. 2003. Founding-family ownership and firm performance: Evidence from the S\&P 500. Journal of Finance, 53: 1301-1328.

Anderson, R., \& Reeb, D. 2004. Board composition: Balancing family influence in S\&P 500 firms. Administrative Science Quarterly, 49: 209-237.

Ang, J., Cole, R., \& Lin, J. 2000. Agency costs and ownership structure. Journal of Finance, 55: 81-106.

Arthur, N. 2001. Board composition as the outcome of an internal bargaining process: Empirical evidence. Journal of Corporate Finance, 7: 307-340.

Baysinger, B., \& Butler, H. 1985. Corporate governance and the board of directors: Performance effects of changes in board composition. Journal of Law, Economics, and Organization, 1: 101-124.

Baysinger, B., \& Hoskisson, R. 1990. The composition of boards of directors and strategic control: Effects on corporate strategy. Academy of Management Review, 15: 72-87.

Bennedsen, M., \& Wolfenzon, D. 2000. The balance of power in closely held corporations. Journal of Financial Economics, 58: 113-139.

Brickley, J., Coles, J., \& Terry, R. 1994. Outside directors and the adoption of poison pills. Journal of Financial Economics, 35: 371-390.

Brickley, J., Lease, R., \& Smith, C. 1988. Ownership structure and voting on anti takeover amendments. Journal of Financial Economics, 20: 267-291.

Bruton, G., Ahlstrom, D., \& Wan, J. 2003. Turnaround in East Asian firms: Evidence from ethnic overseas Chinese communities. Strategic Management Journal, 24: 519-540.

Carney, M., \& Gedajlovic, E. 2002. The coupling of ownership and control and the allocation of financial resources: Evidence from Hong Kong. Journal of Management Studies, 39(1): 123-146.

Carney, M., \& Gedajlovic, E. 2003. Strategic innovation and administrative heritage of East Asian family business groups. Asia Pacific Journal of Management, 20: 5-26.

Chang, S. 2003. Ownership structure, expropriation, and performance of group-affiliated companies in Korea. Academy of Management Journal, 46: 238-254.

Chang, S., \& Hong, J. 2000. Economic performance of group-affiliated companies in Korea: Intragroup resource sharing and internal business transactions. Academy of Management Journal, 43: 429-448.

Chang, E., Cheng, J., \& Khorana, A. 2002. An examination of herd behavior in equity markets: An international perspective. Journal of Banking \& Finance, 24: 1651-1679.

Cho, M.-H. 1998. Ownership structure, investment, and the corporate value: An empirical analysis. Journal of Financial Economics, 47: 103-121.

Claessens, S., Djankov, S., \& Lang, L. 2000. The separation of ownership and control in East Asian corporations. Journal of Financial Economics, 58, 81-112.

Core, J., Holthausen, R., \& Lacker, D. 1999. Corporate governance, chief executive officer compensation, and firm performance. Journal of Financial Economics, 51: 371-406.

Daily, C., \& Dalton, D. 1992. The relationship between governance structure and corporate performance in entrepreneurial firms. Journal of Business Venturing, 7: 375-386.

Daily, C., Johnson, J., \& Dalton, D. 1999. On the measurements of board composition: Poor consistency and a serious mismatch of theory and operationalization. Decision Sciences, 30: 83-106.

Daily, C., Dalton, D., \& Rajagopalan, N. 2003. Governance through ownership: Centuries of practice, decades of research. Academy of Management Journal, 46: 151-158.

Dalton, D., Daily, C., Certo, S., \& Roengpitya, R. 2003. Meta-analysis of financial performance and equity: Fusion or confusion? Academy of Management Journal, 46: 13-26.

Demsetz, H. 1983. The structure of ownership and the theory of the firm. Journal of Law and Economics, 26: $375-390$.

Demsetz, H., \& Lehn, K. 1985. The structure of corporate ownership: Causes and consequences. Journal of Political Economy, 93: 1155-1177.

Denis, D., \& Sarin, A. 1999. Ownership and board structures in publicly traded corporations. Journal of Financial Economics, 52: 187-223.

Economic Daily News. 2002. Editorial; 12th December.

Faccio, M., \& Lasfer, M. 2000. Do occupational pension funds monitor companies in which they hold large stakes? Journal of Corporate Finance, 6: 71-110.

Fama, E., \& Jensen, M. 1983. Separation of ownership and control. Journal of Law and Economics, 26: 301-325. 
Filatotchev, I., \& Bishop, K. 2002. Board composition, share ownership and 'underpricing' of UK IPO firms. Strategic Management Journal, 23(10): 941-955.

Filatotchev, I., Buck, T., \& Zhukov, V. 2000. Downsizing in privatized firms in Russia, Ukraine, and Belarus. Academy of Management Journal, 43: 286-304.

Geletkanycz, M., Boyd, B., \& Finkelstein, S. 2001. The strategic value of CEO external directorate networks: Implications for CEO compensation. Strategic Management Journal, 22: 889-898.

Golden, B., \& Zajac, E. 2001. When will boards influence strategy? Inclination $\times$ power $=$ strategic change. Strategic Management Journal, 22: 1087-1111.

Gomes-Mejia, L., Nunez-Nickel, M., \& Guttierrez, I. 2001. The role of family ties in agency contracts. Academy of Management Journal, 44: 81-95.

Gomes-Mejia, L., Larraza-Kintana, M., \& Makri, M. 2003. The determinants of executive compensation in familycontrolled public corporations. Academy of Management Journal, 46: 226-237.

Hambrick, D., \& Jackson, E. 2000. Outside directors with stake: The linchpin in improving governance. California Management Review, 42: 108-127.

Hansmann, H. 1996. The ownership of enterprise. Cambridge: Harvard University Press.

Hanson, R., \& Song, M. 2000. Managerial ownership, board structure, and the division of gains in divestitures. Journal of Corporate Finance, 6: 55-70.

Himmelberg, C., Hubbard, R., \& Palia, D. 1999. Understanding the determinants of managerial ownership and the link between ownership and performance. Journal of Financial Economics, 53: 353-384.

Holderness, C., \& Sheehan, D. 1988. The role of majority shareholders in publicly held corporations. Journal of Financial Economics, 20: 317-346.

Hoskisson, R., Johnson, R., \& Moesel, D. 1994. Corporate divestiture intensity in restructuring firms: Effects of governance, strategy and performance. Academy of Management Journal, 37: 1207-1251.

Hoskisson, R., Hitt, M., Johnson, R., \& Grossman, W. 2002. Conflicting voices: The effects of institutional ownership heterogeneity and internal governance on corporate innovation strategies. Academy of Management Journal, 45: 697-716

James, H. 1999. Owner as manager, extended horizons and the family firm. International Journal of the Economics of Business, 6(1): 41-55

Jensen, M., \& Meckling, W. 1976. Theory of the firm: managerial behavior, agency costs, and ownership structure. Journal of Financial Economics, 3: 305-360.

Joh, S. 2003. Corporate governance and firm profitability: evidence from Korea before the economic crisis. Journal of Financial Economics, 68: 287-322.

Johnson, R., \& Greening, D. 1999. The effects of corporate governance and institutional ownership types on corporate social responsibility. Academy of Management Journal, 42(5): 564-576.

Khanna, T., \& Palepu, K. 1997. Why focused strategies may be wrong for emerging markets. Harvard Business Review, 75(July-August): 3-10.

Khanna, T., \& Palepu, K. 2000. The future of business groups in emerging markets: Long-run evidence from Chile. Academy of Management Journal, 43: 268-285.

Kochar, R., \& David, P. 1996. Institutional investors and firm innovation: A test of conflicting hypotheses. Strategic Management Journal, 17: 73-84.

Kroszner, R., \& Strahan, P. 2001. Bankers on boards: Monitoring, conflicts of interest, and lender liability. Journal of Financial Economics, 62: 415-452.

La Porta, R., Lopez-De-Silanes, F., \& Shleifer, A. 1999. Corporate ownership around the world. Journal of Finance, 54: 471-514.

La Porta, R., Lopez-De-Silanes, F., Shleifer, A., \& Vishny, R. 1998. Law and finance. Journal of Political Economy, 106: 1113-1155

La Porta, R., Lopez-De-Silanes, F., Shleifer, A., \& Vishny, R. 1997. Legal determinants of external finance. Journal of Finance, 52: 1131-1150.

La Porta, R., Lopez-De-Silanes, F., Shleifer, A., \& Vishny, R. 2000a. Investor protection and corporate governance. Journal of Financial Economics, 58: 3-27.

La Porta, R., Lopez-De-Silanes, F., Shleifer, A., \& Vishny, R. 2000b. Agency problem and dividend policies around the world. Journal of Finance, 55: 1-33. 
Mak, Y., \& Li, Y. 2001. Determinants of corporate ownership and board structure: Evidence from Singapore. Journal of Corporate Finance, 7: 235-256.

Maug, E. 1998. Large shareholders as monitors: is there a trade-off between liquidity and control? Journal of Finance, 53: 65-98.

McConaughy, D., Matthews, C., \& Fialko, A. 2001. Founding family controlled firms: Performance, risk and value. Journal of Small Business Management, 39: 31-49.

McConnell, J., \& Servaes, H. 1990. Additional evidence on equity ownership and corporate value. Journal of Financial Economics, 27: 595-612.

Mitton, T. 2002. A cross-firm analysis of the impact of corporate governance on the East Asian financial crisis. Journal of Financial Economics, 64: 215-241.

Morck, R., Shleifer, A., \& Vishny, R. 1988. Managerial ownership and market valuation: An empirical analysis. Journal of Financial Economics, 20: 292-315.

Newman, K. 2000. Organizational transformation during institutional upheaval. Academy of Management Review, 25: 602-619.

North, D. 1990. Institutions, institutional change, and economic performance. Cambridge; New York: Cambridge University Press,

Numazaki, I . 1993. The Tainanbang: The rise and growth of a banana-bunch-shaped business group in Taiwan. Developing Economies, 31: 485-510.

Ocasio, W., \& Kim, H. 1999. The circulation of corporate control: Selection of functional backgrounds of new CEOs in large US manufacturing firms, 1981-1992. Administrative Science Quarterly, 44: 532-562.

Oswald, S., \& Jahera, J. 1991. The influence of ownership on performance: An empirical study. Strategic Management Journal, 12: 321-326.

Pagano, M., \& Röell, A. 1998. The choice of stock ownership structure: Agency costs, monitoring, and the decision to go public. Quarterly Journal of Economics, 113: 187-225.

Peng, M. W. 2004. Outside directors and firm performance during institutional transitions. Strategic Management Journal, 25: 435-471.

Pfeffer, J. 1972. Size and composition of corporate boards of directors: The organization and its environment Administrative Science Quarterly, 17: 218-222.

Pound, J. 1988. Proxy contests and the efficiency of shareholder oversight. Journal of Financial Economics, 20 : 237-265.

Provan, K. 1980. Board power and organizational efficiency among human service agencies. Academy of Management Journal, 23: 221-236.

Rajan, R., \& Zingales, L. 1988. Which capitalism? Lessons from the East Asian Crisis. Journal of Applied Corporate Finance, 11(3): 40-48.

Rediker, K. J., \& Seth, A. 1995. Boards of directors and substitution effects of alternative governance mechanisms. Strategic Management Journal, 16: 85-99.

Schulze, W., Lubatkin, M., Dino, R., \& Buchholtz, A. 2001. Agency Relationships in Family Firms: Theory and Evidence. Organization Science, 12: 99-116.

Schulze, W., Lubatkin, M., \& Dino, R. 2003. Exploring the agency consequences of ownership dispersion among the directors of private family firms. Academy of Management Journal, 46: 217-229.

Shivdasani, A., \& Yermack, D. 1999. CEO involvement in the selection of new board members: An empirical analysis. Journal of Finance, 54: 1829-1853.

Shleifer, A., \& Vishny, R. 1997. A survey of corporate governance. Journal of Finance, 52: 737-783.

Short, H. 1994. Ownership, control, financial structure and the performance of firms. Journal of Economic Surveys, 8: 203-249.

Singh, M., \& Davidson III, W. 2002. Agency costs, ownership structure and corporate governance mechanisms. Journal of Banking \& Finance.

Smith, B., \& Amoako-Adu, B. 1999. Management succession and financial performance of family controlled firms. Journal of Corporate Finance, 5: 341-368.

Taniura, T. 1989. Management in Taiwan: The case of the Formosa plastics group. East Asian Cultural Studies, 28: $21-46$.

Taniura, T. 1993. The Lucky Goldstar group in the Republic of Korea. Developing Economies, 31: 465-484.

Taylor, W. 1990. Can big owners make a difference?. Harvard Business Review, 68(2): 70-82. 
Teece, D. 1980. Economies of Scope and the Scope of the Enterprise. Journal of Economic Behaviour and Organization, 3, 223-247.

Tihanyi, L., Johnson, R., Hoskisson, R., \& Hitt, M. 2003. Institutional ownership differences and international diversification: The effects of boards of directors and technological opportunity. Academy of Management Journal, 46: 195-211.

Thomsen, S., \& Pedersen, T. 2000. Ownership structure and economic performance in the largest European companies. Strategic Management Journal, 21: 689-705.

Wealth Magazine, May, 2002.

Wiseman, R. M., \& Gomez-Mejia, L. R. 1998. A behavioral agency model of managerial risk taking. Academy of Management Review, 23(1): 133-153.

Woidtke, T. 2002. Agents watching agents? Evidence from pension fund ownership and firm value. Journal of Financial Economics, 63: 99-131.

Wruck, K. 1989. Equity ownership concentration and firm value. Evidence from private equity financing. Journal of Financial Economics, 23: 3-28.

Xie, B., Davidson III, W., \& DaDalt, P. 2002. Earnings management and corporate governance: The role of the board and the audit committee. Journal of Corporate Finance.

Young, M., Ahlstrom, D., Bruton, G., \& Chan, E. 2001. The resource dependence, service and control functions of board of directors in Hong Kong and Taiwanese firms. Asian Pacific Journal of Management, 18(Special Issue): 223-244

Young, M., Peng, M., Ahlstrom, D., \& Bruton, G. 2002. Governing the corporation in emerging economies: A principal-principal perspective, In Best Paper Proceedings, Academy of Management Annual Meeting, August, Denver, CO.

Zahra, S., \& Pearce, J. 1989. Boards of directors and corporate financial performance: A review and integrative model. Journal of Management, 15: 291-334.

Zeckhauser, R., \& Pound, J. 1990. Are large shareholders effective monitors? An investigation of share ownership and corporate performance, In R. G. Hubbard (ed.). Asymmetric Information, Corporate Finance and Investment, The University of Chicago Press: Chicago and London; pp. 149-180.

Zhou, X. 2001. Understanding the determinants of managerial ownership and the link between ownership and performance: Comment. Journal of Financial Economics, 62: 559-571. 